\title{
IMPLEMENTASI PENGGUNAAN MEDIA KARTU ANGKA UNTUK MENINGKATKAN KEMAMPUAN BERHITUNG PADA ANAK
}

\author{
Sri Sufliati Romba ${ }^{1}$, Fadhilah Latif ${ }^{2}$ \\ Fakultas Keguruan dan Ilmu Pendidikan, Universitas Muhammadiyah Makassar ${ }^{1,2}$ \\ srisufliati79@gmail.com ${ }^{1}$, fadhilah.latief@unismuh.ac.id ${ }^{2}$ \\ Romba, Sri Sufliati,. Fadhilah Latif. (2021). Implementasi Penggunaan Media Kartu Angka untuk \\ Meningkatkan Kemampuan Berhitung pada Anak. Jurnal Pelita PAUD, 6(1), 118-126. \\ doi: https://doi.org/10.33222/pelitapaud.v6i1.1488
}

\begin{abstract}
Abstrak: Tujuan penelitian ini yaitu untuk mengetahui peningkatan kemampuan berhitung anak usia dini melalui penerapan metode bermain kartu angka. Jenis penelitian ini adalah Penelitian Tindakan Kelas (Class Action Room) yang terdiri dari dua siklus, setiap siklus dilaksanakan sebanyak dua kali pertemuan. Prosedur penelitian meliputi perencanaan, pelaksanaan, observasi dan refleksi. Subjek dalam penelitian ini adalah Kelompok B Taman Kanak-kanak Bukit Permai Agang Je'ne Kelurahan Empoang Kecamatan Binamu Kabupaten Jeneponto sebanyak 15 anak. Subjek penelitian dipilih berdasarkan teknik convenience sampling. Indikator peningkatan dilihat dari dari hasil observasi kemampuan anak pada siklus I ke siklus ke II. Hasil penelitian menunjukkan implementasi penggunaan media kartu angka dapat meningkatkan kemampuan berhitung anak usia dini. Lebih dari $75 \%$ anak mencapai kategori baik. Adapun temuan penelitian ini yaitu tahap perencanaan dan komunikasi antara guru dan anak memengaruhi pencapaian tujuan pembelajaran.
\end{abstract}

Kata kunci : Anak, Kemampuan Berhitung, Media kartu angka.

Abstract: The purpose of this study is to determine the improvement of early childhood numeracy skills through the application of the number card playing method. This type of research is Class Action Research (Class Action Room) which consists of two cycles, each cycle is carried out in two meetings. The research procedure includes planning, implementation, observation and reflection. The subjects in this study were Group B Kindergarten at Bukit Permai Agang Je'ne, Epoang Village, Binamu District, Jeneponto Regency with 15 children. Research subjects were selected based on convenience sampling technique. Indicators of improvement are seen from the results of observations of children's abilities in the first cycle to the second cycle. The results of the study show that the implementation of the use of number card media can improve early childhood numeracy skills. More than 75\% of students achieved good category. The findings of this study are that the planning and communication stages between teachers and students affect the achievement of learning objectives

Keywords : Children, Counting Ability, Number card media

http://jurnal.upmk.ac.id/index.php/pelitapaud 
P ISSN 2548-6284 E ISSN 2615-0360

Vol. 6 No. 1 Desember 2021

\section{PENDAHULUAN}

Pendidikan mengambil peran penting dalam menopang perkembangan potensi manusia untuk mempertahankan hidupnya. Berbagai sistem pendidikan dirancang guna menanamkan nilai-nilai kebudayaan dan sosial yang tujuannya merujuk pada keberlangsungan hidup manusia (Hurlock, 2010). Dengan demikian, pendidikan sangat esensial bagi semua orang di berbagai tingkatan usia termasuk anak usia dini. Justru mereka yang masih dalam tahap perkembangan fisik, kognitif psikomotorik harus dibekali berbagai kemampuan dasar (Aritonang and Elshap, 2019:364; Oktriyani, 2017:86). Kemampuan tersebut dimaksudkan agar mereka tumbuh menjadi pribadi yang cerdas dan berperilaku baik.

Salah satu kemampuan kognitif yang perlu mereka kuasai yakni kemampuan berhitung karena kemampuan ini digunakan dalam kehidupan sehari-hari (Aritonang and Elshap, 2019:364) dan dalam pemecahan masalah terkait persoalan matematika (Novianti, 2015:56). kemampuan berhitung adalah kemampuan tentang bilangan-bilangan, hubungan antar bilangan dan prosedur operasional yang digunakan dalam penyelesaian persoalan mengenai bilangan (Novan, 2016).

Konsep berhitung pada pendidikan pada anak usia dini sangat diperlukan untuk membangun pengetahuan dasar matematika yang akan digunakan pada pendidikan selanjutnya. Kemampuan ini juga berguna dalam perkembangan kecerdasan logika matematika anak (Setiawan, 2018:183). Maka usia dini adalah masa yang sangat strategis untuk mengenalkan berhitung pada jalur matematika, karena pada usia ini anak sangat peka terhadap rangsangan yang diterima dari lingkungan. Usia ini juga disebut sebagai masa emas atau the golden age (Setiawan, 2018:182). Oleh karena itu, pendidikan di TK berperan dalam mengoptimalkan tumbuh kembang mereka.

Kegiatan menghitung pada anak usia 5-6 tahun di TK menuntut mereka untuk bisa membilang angka 1-10, menghitung benda 110, membaca bilangan 1-10 dan menghubungkan benda dengan bilangan 1-10 (Novianti, 2015:56). Faktanya, beberapa temuan dari studi sebelumnya menunjukkan kemampuan berhitung anak usia dini masih dalam kategori rendah (Laily et al., 2019; Farihah, 2017:8). Pernyataan tersebut semakin diperkuat dengan hasil observasi peneliti pada anak usia dini di Taman Kanak-Kanak TK Bukit Permai Agang Je'ne Kecamatan Binamu Kabupaten Jeneponto memiliki kemampuan berhitung yang rendah.

Anak-anak cenderung kurang tertarik dengan metode ini, sehingga anak cenderung pasif dan tidak antusias dalam pembelajaran serta anak-anak cenderung bosan, bahkan anak akan lebih banyak bercerita dengan temannya. Hal yang sama juga ditemui dalam studi Malapata and Wijayanigsih (2019:284). Malapata menyebutkan permasalahan ini disebabkan karena media yang digunakan masih kurang mendukung pembelajaran. Selain itu kegaiatan yang monoton seperti penggunaan metode ceramah juga membuat siswa mudah bosan dalam belajar (Farihah, 2017:2). Dalam studi observasi ini, guru lebih cenderung menggunakan metode ceramah. Teknik dalam proses pembelajaran yang digunakan kurang menggunakan teknik bermain khususnya dalam pembelajaran dan pengenalan angka dan bilangan dalm proses pembelajran berhitung anak, salah satu alasannya karena media yang digunakan oleh guru akan memakan banyak biaya, dan perlu persiapan yang lama, menuntut kreativitas guru dan lain-lain.

Penggunaan media pembelajaran sangat menentukan keberhasilan pembelajaran sehingga harus disesuaikan dnegan kebutuhan anak (Romlah, Kurniah and Wembrayarli, 2016:17). Media pembelajaran berkontribusi menghapus momok belajar matematika yang dianggap sebagai pelajaran sulit dan kurang menyenangkan. Media membantu mereka menerima pemahaman dalam konteks sederhana dan menciptakan suasana belajar yang menyenangkan (Setiawan, 2018:183) melalui wahana permainan bagi anak usia dini (Farihah, 2017:5) karena mereka sangat menyukai kegiatan bermain sehingga metode bermain sangat baik digunakan untuk mengenalkan bilangan kepada anak TK. Ada banyak proses kegiatan bermain dapat digunakan dalam pengenalan berhitung, diantaranya bermain kartu angka, bermain lompat angka, dan bermain berapa biji, dan lain-lain. 
P ISSN 2548-6284 E ISSN 2615-0360

Vol. 6 No. 1 Desember 2021

Beberapa studi sebelumnya telah menggunakan kartu angka untuk meningkatkan ranah kognitif anak usia dini, misalnya studi Mufarizuddin, (2017) mengemukakan adanya peningkatan kecerdasan logika matematika anak usia dini setelah diterapkan media kartu angka. Ulfah, (2018:72) juga menggunakan kartu angka dalam mengenal angka. Penelitian tersebut lebih fokus pada pengenalan angka pada anak usia dini namun belum berfokus pada peningkatan kemampuan berhitung. Oleh karena itu studi berfokus pada peningkatan kemampuan berhitung anak yakni implementasi penggunaan kartu angka untuk meningkatkan kemampuan berhitung anak di taman kanak kanak Bukit Permai Agang Je'ne kabupaten Jeneponto. Studi ini dimaksudkan untuk mengisi literatur terkait peningkatan kemampuan berhitung menggunakan kartu angka. Adapun tujuan penelitian ini adalah untuk untuk mengetahui peningkatan kemampuan berhitung melalui penerapan metode bermain kartu angka di TK Bukit Permai Agang Je'ne Kelurahan Empoang, Kec. Binamu Kab. Jeneponto.

\section{METODE PENELITIAN}

\section{Jenis Penelitian}

Jenis penelitian yang digunakan yaitu Penelitian Tindakan Kelas (PTK). Penelitian tindakan kelas ini dilakukan untuk memperbaiki dan meningkatkan kualitas pembelajaran yang dilakukan oleh guru dan bagi penulis sendiri untuk memperoleh hasil belajar yang baik serta memuaskan (Arikunto, 2010).

\section{Waktu dan Tempat Penelitian}

Penelitian ini dilaksanakan di TK Bukit Permai Agang Je'ne Kelurahan Empoang Kecamatan Binamu Kabupaten Jeneponto. Penelitian dilaksanakan pada bulan Juni Tahun Ajaran 2020-2021.

\section{Subjek Penelitian}

Adapun subjek dalam penelitian ini adalah anak didik kelompok B dengan jumlah 15 anak didik dan 1 orang guru. Studi ini menggunakan teknik convenience sampling dalam penentuan sampel. Teknik ini merupakan pemilihan sampel secara bebas sesuai dengan kehendak peneliti dan tanpa melalui perhitungan statistik sehingga memudahkan peneliti. Peneliti hanya mempertimbangkan ketersediaan sampel dan kecocokan karakteristik sampel (T. Widodo \& Solehudin, 2021). Menurut Farrokhi \& Mahmoudi-Hamidabad (2012) penentuan sampel mempertimbangkan kriteria praktis seperti kedekatan geografis, kemudahan akses, ketersediaan sampel di lokasi dan kesediaan sampel Oleh karena itu, teknik ini dipilih untuk memudahkan peneliti dalam pengumpulan data di masa pandemi COVID19.

\section{Prosedur}

Penelitian ini dilakukan secara bersiklus, yang dimulai dari kondisi awal kemudian siklus pertama dan lanjut siklus kedua dengan prosedur dari penelitian yang akan peneliti lakukan terdiri atas empat tahapan penting penelitian tindakan kelas meliputi: a) perencanaan, b) pelaksanaan, c) pengamatan, d) refleksi. Jika dalam siklus I belum berhasil dan meningkat, peneliti akan melakukan perbaikan kegiatan pembelajaran berdasarkan hal-hal yang belum dicapai pada siklus I. Pada siklus II ini akan dilakukan sama dengan siklus I yaitu perencanaan, pelaksanaan, pengamatan, dan refleksi.

\section{Data, Intrumen, dan Teknik Pengumpulan Data}

Teknik pengumpulan data yang digunakan adalah observasi, dan dokumentasi (Mulyasa, 2010) meliputi observasi dan dokumentasi.

\section{Observasi}

Adapun pengumpulan data melalui observasi dilakukan sendiri oleh peneliti dibantu oleh guru kelas. Observasi dilakukan di kelas yang akan dijadikan subyek penelitian sehingga peneliti mendapatkan gambaran secara langsung kegiatan belajar anak dikelas.Adapun yg menjadi hal-hal yang diobservasi pada anak didik yaitu kemampuan anak membilang /menyebut urutan bilangan dari 1-10, kemampuan anak membilang dengan menunjuk benda (mengenal kemampuan berhitung dengan benda-benda) dari 1-5, kemampuan anak menunjukkan urutan benda untuk bilangan dari 1-5, kemampuan anak menghubungkan/memasangkan lambang bilangan dengan benda-benda dari 1-5 dan kemampuan anak dalam menyebutkan kembali benda-benda yang baru dilihat oleh anak didik. Sedangkan pada guru observasi yang dilakukan meliputi bagaimana pelaksanaan 
PISSN 2548-6284 E ISSN 2615-0360

Vol. 6 No. 1 Desember 2021

permainan kartu angka yang dilaksnakan oleh guru untuk meningkatkan kemampuan berhitung anak dan anak. Proses observasi menggunakan lembar observasi anak didik dan lembar observasi guru.

Dokumentasi

Dokumentasi adalah metode untuk memperoleh informasi atau mengetahui sesuatu dengan buku-buku, arsip yang berhubungan dengan yang diteliti. Dokumentasi digunakan untuk memperoleh data satuan dan nama-nama anak didik kelompok B.

Pada penelitian ini, adapun data dianalisis sejak tindakan kegiatan pembelajaran dilakukan dan akan dikembangkan selama proses refleksi samaipada proses penyusunan laporan. Untuk menghasilkan akhir dari penelitian ini maka digunakan analisis dengan cara reduksi data, penyajian data dan penarikan kesimpulan.

Teknik Analisis Data

Teknik yang digunakan dalam penelitian ini adalah deskriptif analitik dengan penjelasan sebagai berikit:

Data kuantitatif yang diperoleh dari lembar hasil belajar diolah menggunakan persentase

$$
P=\frac{J S S}{J S} \times 100 \%
$$

Keterangan:

$\mathrm{P}=$ Persentase

JSS=Jumlah siswa dalam skor

$\mathrm{JS}=$ Jumlah siswa

Data kualitatif diperoleh dari lembar observasi yang diklasifikasi berdasarkan aspek-aspek yang dijadikan focus analisis.

Penilaian hasil belajar penelitian ini didasarkan pada buku-buku pedoman penelitian di Taman Kanak-kanak Direktorat Pendidik Anak Usia Dini Departemen Pendidikan Nasional, 2007 secara kualitatif dalam tabel 1 sedangkan pedoman observasi guru disajikan dalam tabel 2 .

Tabel 1. Pedoman observasi

No Kategori $\quad$ Kemampuan Simbol

\begin{tabular}{|c|c|c|c|}
\hline 1 & Baik & $\begin{array}{l}\text { Anak didik dapat } \\
\text { melakukan } \\
\text { perlakuan } \\
\text { dengan baik, } \\
\text { cekatan secara } \\
\text { benar dan tepat }\end{array}$ & \\
\hline 2 & Cukup & $\begin{array}{l}\text { Anak didik dapat } \\
\text { melakukan } \\
\text { perlakuan } \\
\text { dengan baik, } \\
\text { sedikit lamban } \\
\text { secara benar dan } \\
\text { tepat }\end{array}$ & $\sqrt{ }$ \\
\hline 3 & Kurang & $\begin{array}{l}\text { Anak didik tidak } \\
\text { dapat melakukan } \\
\text { perlakuan } \\
\text { dengan baik, } \\
\text { lamban, kadang } \\
\text { salah dan kurang } \\
\text { tepat }\end{array}$ & $\mathrm{O}$ \\
\hline
\end{tabular}

Tabel 2. Pedoman Observasi Guru Dalam Pelaksanaan Pembelajaran

\begin{tabular}{l} 
Indikator \\
\hline $\begin{array}{l}\text { Kuru menyediakan kartu angka dan } \\
\text { kartu gambar }\end{array}$ \\
Guru menjelaskan tugas-tugas yang \\
akan dikerjakan \\
Letakkan semua potongan kartu di \\
atas meja. Anak-anak mencoba \\
untuk mencocokkan kartu angka \\
dengan kartu gambar kesempatan \\
Guru memberikan bermain \\
kepada anak mencoba bak \\
mencari kartu angka yang sesuai \\
dengan jumlah gambar \\
\hline Permainan ini terus berlanjut, \\
sampai semua anak mencoba \\
permainannya
\end{tabular}

\section{HASIL PENELITIAN DAN} PEMBAHASAN

\section{Hasil Penelitian}

Hasil dalam penelitian tindakan kelas ini akan membahas tentang hasil yang diperoleh pada setiap siklus implementasi penggunaan media kartu angka untuk meningkatkan kemampuan berhitung pada anak. Penelitian ini dimulai dari tahapan perencanaan, pelaksanaan, observasi, dan refleksi pada setiap siklusnya. Setelah proses perencanaan dan pelaksanaan dilakukan tahap observasi. peneliti bertindak sebagai observer melakukan pengamatan dan mencatat perkembangan dan kegiatan yang dilaksanaksanakan oleh guru pada saat 
P ISSN 2548-6284 E ISSN 2615-0360

Vol. 6 No. 1 Desember 2021

menyampaikan materi dan anak anak didik pada aspek peningkatan kemampuan

Berikut dijabarkan secara rinci hasil observasi dan refleksi pada setiap pertemuannya.

Hasil Siklus I pertemuan I

Pada tahap observasi guru tahap siklus 1 pertemuan 1 ini masih pada kategori cukup.

Berikut pada tabel 3 disajikan pencapaian indikator dan kategorinya sedangkan hasil observasi siswa disajikan pada gambar 1 .

Tabel 3. Hasil observasi guru pada pelaksanaan siklus I pertemuan I

\begin{tabular}{lc}
\hline \multicolumn{1}{c}{ Indikator } & Kategori \\
\hline $\begin{array}{l}\text { Guru menyediakan kartu angka dan } \\
\text { kartu gambar }\end{array}$ & Cukup \\
\hline $\begin{array}{l}\text { Guru menjelaskan tugas-tugas yang } \\
\text { akan dikerjakan }\end{array}$ & Cukup \\
\hline $\begin{array}{l}\text { Letakkan semua potongan kartu di } \\
\text { atas meja. Anak-anak mencoba }\end{array}$ & Cukup \\
untuk mencocokkan kartu angka & \\
dengan kartu gambar & \\
\hline $\begin{array}{l}\text { Guru memberikan kesempatan } \\
\text { kepada anak mencoba bermain } \\
\text { mencari kartu angka yang sesuai } \\
\text { dengan jumlah gambar }\end{array}$ & \\
\hline $\begin{array}{l}\text { Permainan ini terus berlanjut, } \\
\text { sampai semua anak mencoba } \\
\text { permainannya }\end{array}$ & Cukup \\
\hline
\end{tabular}

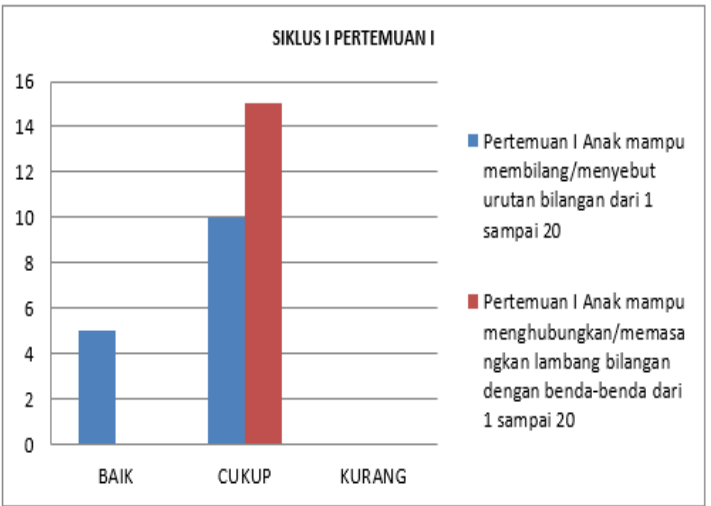

Gambar 1. Hasil observasi anak pada pertemuan 1 siklus 1 .

Pada gambar menunjukkan 33\% dari anak berada dalam kategori baik dalam mengurutkan gambar pelangi 1-20 tanpa bimbingan guru.

Hasil Siklus I pertemuan II

Pada tahap observasi guru tahap siklus 1 pertemuan II ini masih pada kategori cukup. Berikut pada tabel 4 disajikan pencapaian indikator dan kategorinya dan pada gambar 2 disajikan observasi siswa.

Tabel 4. Hasil observasi guru pada pelaksanaan siklus I pertemuan II
Implementasi Penggunaan Media .... Sri Sufliati Romba, Fadhilah Latif

\begin{tabular}{lc}
\hline \multicolumn{1}{c}{ Indikator } & Kategori \\
\hline $\begin{array}{l}\text { Guru menyediakan kartu angka dan } \\
\text { kartu gambar }\end{array}$ & Cukup \\
\hline $\begin{array}{l}\text { Guru menjelaskan tugas-tugas yang } \\
\text { akan dikerjakan }\end{array}$ & Cukup \\
\hline $\begin{array}{l}\text { Letakkan semua potongan kartu di } \\
\text { atas meja. Anak-anak mencoba }\end{array}$ & Cukup \\
untuk mencocokkan kartu angka &
\end{tabular}

dengan kartu gambar

Guru memberikan kesempatan

kepada anak mencoba bermain

mencari kartu angka yang sesuai

Cukup

dengan jumlah gambar

Permainan ini terus berlanjut,
sampai semua anak mencoba Cukup
permainannya
permainannya

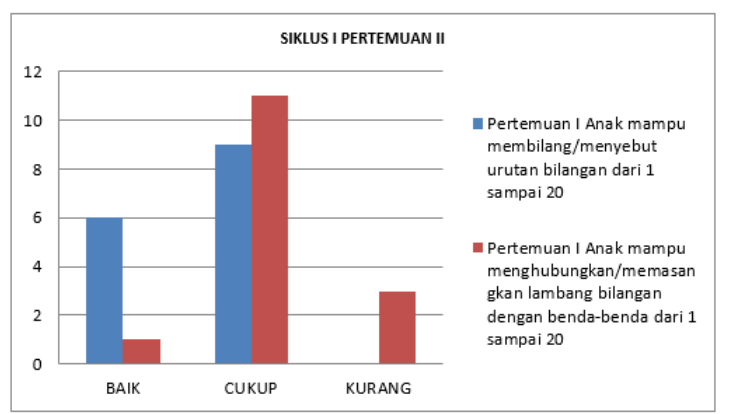

Gambar 2. Hasil observasi siswa pada siklus I pertemuan II.

Pada gambar 2 terlihat hanya $40 \%$ anak dalam kategori baik pada menghubungkan dan memasangkan lambang bilangan dengan benda 1-20 tanpa bimbingan guru.

Hasil observasi yang dilakukan pada pelaksanaan siklus I pertemuan pertama dan ke-II menunjukkan bahwa masih ada beberapa kelemahan yang dilakukan dalam proses pembelajaran dimana guru masih memberikan penjelasan tidak jelas sehingga anak masih kaku memahami tugas yang diberikan. Guru juga masih menggunakan media kartu secara terbatas, anak tidak diberikan reward atau penghargaan atas hasil yang mereka peroleh. Pada aspek anak masih kaku karena anak belum terbiasa dengan kegiatan yang dilakukan. Berdasarkan dari data tersebut maka pelaksanaan pembelajaran siklus I masih belum mencapai target indikator yang telah ditetapkan yaitu $75 \%$ anak berada dalam kategori baik. Sehingga peneliti akan melanjutkan pada pelaksanaan siklus II dengan memperbaiki segala kekurangan pada pelaksanaan siklus I

Hasil Siklus II pertemuan I 
P ISSN 2548-6284 E ISSN 2615-0360

Vol. 6 No. 1 Desember 2021

Setelah siklus I dilakukan siklus lanjutan (siklus II) untuk melihat peningkatan kemampuan berhitung anak menggunakan kartu angka. Pada tahap observasi guru tahap siklus 2 pertemuan 1 ini masih pada kategori baik. Berikut pada tabel 5 disajikan pencapaian indikator dan kategorinya sedangkan hasil observasi siswa disajikan pada gambar 3 .

Tabel 5. Hasil observasi guru pada pelaksanaan siklus II pertemuan I

\begin{tabular}{lc}
\hline \multicolumn{1}{c}{ Indikator } & Kategori \\
\hline $\begin{array}{l}\text { Guru menyediakan kartu angka dan } \\
\text { kartu gambar } \\
\text { Guru menjelaskan tugas-tugas yang } \\
\text { akan dikerjakan }\end{array}$ & Baik \\
\hline $\begin{array}{l}\text { Letakkan semua potongan kartu di } \\
\text { atas meja. Anak-anak mencoba }\end{array}$ \\
untuk mencocokkan kartu angka & Baik \\
dengan kartu gambar & \\
$\begin{array}{l}\text { Guru memberikan kesempatan } \\
\text { kepada anak mencoba bermain } \\
\text { mencari kartu angka yang sesuai } \\
\text { dengan jumlah gambar }\end{array}$ & \\
\hline $\begin{array}{l}\text { Permainan ini terus berlanjut, } \\
\text { sampai semua anak mencoba } \\
\text { permainannya }\end{array}$ & Baik \\
\hline
\end{tabular}

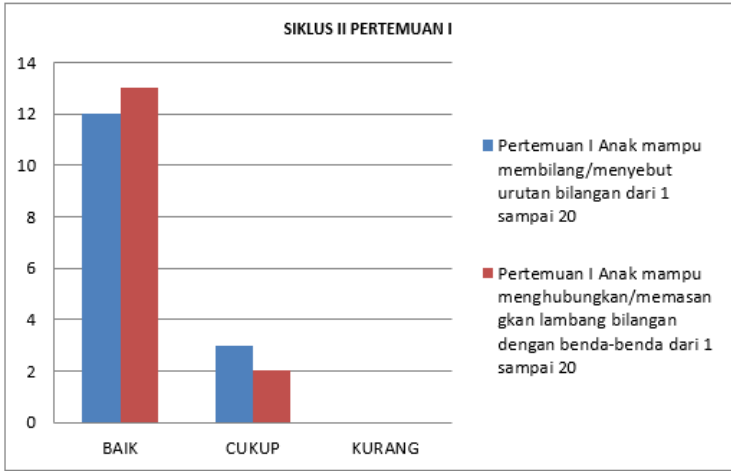

Gambar 3. Hasil observasi siswa pada siklus II pertemuan I.

Terdapat $86 \%$ anak mampu mengurutkan gambar pelangi 1-20. tanpa bimbingan guru.

Hasil Siklus II pertemuan II

Berikut pada tabel 6 disajikan hasil observasi pada guru saat pelaksanaan pembelajaran di kelas dan pada gambar 4 disajikan hasil observasi anak.

Tabel 5. Hasil observasi guru pada pelaksanaan siklus II pertemuan II.

\begin{tabular}{lc}
\hline \multicolumn{1}{c}{ Indikator } & Kategori \\
\hline $\begin{array}{l}\text { Guru menyediakan kartu angka dan } \\
\text { kartu gambar }\end{array}$ & Baik \\
\hline
\end{tabular}

Guru menjelaskan tugas-tugas yang akan dikerjakan Baik

Letakkan semua potongan kartu di atas meja. Anak-anak mencoba untuk mencocokkan kartu angka Baik dengan kartu gambar

Guru memberikan kesempatan

kepada anak mencoba bermain mencari kartu angka yang sesuai Baik dengan jumlah gambar

Permainan ini terus berlanjut, sampai semua anak mencoba Baik permainannya

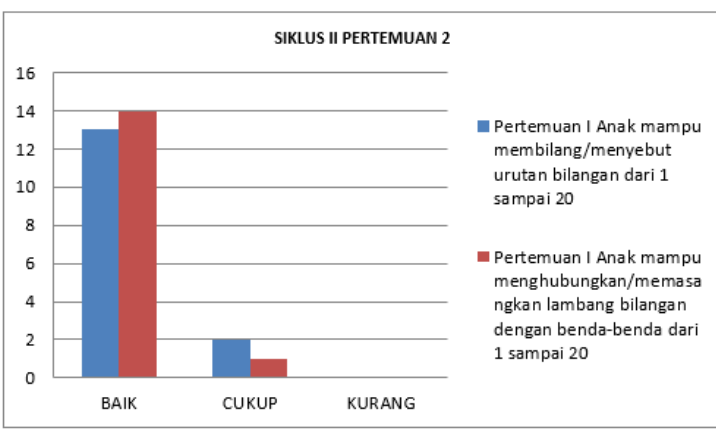

Gambar 4. Hasil observasi siswa pada siklus II pertemuan II.

Terdapat $93 \%$ anak mampu menghubungkan dan memasnagkan lanlmbang bilangan dengan benda 1-20. tanpa bimbingan guru.

Hasil observasi yang dilakukan pada pelaksanaan siklus I pertemuan pertama dan kedua menunjukkan bahwa telah terajdi peningkatan dari hasil pada pelaksanaan siklus I. Dari hasil observasi menunjukkan bahwa sudah tidak ada lagi anak yang memperoleh kategori kurang. Pada siklus II guru telah berbenah untuk memberi reward pada anak usia dini yang memiliki kinerja yang baik dalam berhitung. Maka untuk menentukan keberhasilan maka dirumuskan indikator kinerja yang digunakan sebagai acuan keberhasilan. Adapun keberhasilan penelitian ini adalah pengembangan kemampuan berhitung anak didik mengalami peningkatan lebih dari $75 \%$. berada dalam kategori baik. Dari total anak yang hadir pada setiap pertemuan sebanyak 15 anak didik. Berdasarkan dari data ini maka peneliti tidak melanjutkan lagi pada siklus berikutnya.

Dari hasil penelitian menunjukkan media kartu angka dapat meningkatkan kemampuan berhitung anak usia dini, selain itu peneliti mengidentifikasi pemberian reward pada siswa ikut berkontribusi dalam peningkatan 
P ISSN 2548-6284 E ISSN 2615-0360

Vol. 6 No. 1 Desember 2021

kemampuan tersebut. Hal ini dibuktikan pada siklus pertama peserta didik belum diberi reward oleh guru yang membuat siswa belum tertarik untuk berhitung. Namun, setelah pemberian reward pada tahap siklus ke-dua peserta didik mulai tertarik dan aktif dalam pembelajaran berdasarkan pada hasil observasi. Dengan demikian selain media pembelajaran yang digunakan, pemberian reward pada siswa dapat membuat siswa terlibat aktif di dalam kelas.

\section{Pembahasan}

Pada studi implementasi penggunaan media kartu angka pada anak usia dini yang mengenyam pendidikan di TK mengalami peningkatan kemampuan berhitung. Studi ini mendapatkan temuan ketidaktercapaian indikator kinerja yaitu sekitar 75\% anak mencapai kategori baik pada siklus I disebabkan dua penyebab yakni persiapan pembelajaran yang belum maksimal dan pola komunikasi yang terjalin di dalam kelas.

Perencanaan yang belum maksimal diitunjukkan dengan media kartu angka yang terbatas. Kondisi ini menjadi hambatan dalam implementasi media kartu angka. Menurut Sufiati and Afifah (2019:52) guru sebagai perancang, pengelola, dan pelaksana pembelajaran harus membuat perencanaan untuk dapat mengoptimalkan hasil ketercapaian tujuan pembelajaran. Jika guru tidak mempersiapkan perencanaan yang baik maka di dalam kelas kerap kali mengulang memberikan informasi mengenai kegiatan anak satu persatu (Sufiati and Afifah, 2019:52) Mempersiapkan media pembelajaran merupakan aksi pendidik untuk memberikan informasi yang utuh pada anaknya (Aulina, 2018:11) atau mengefektifkan komunikasi di kelas (Miswara et al., 2018:703). Media pembelajaran memiliki peranan sangat penting pada proses belajar terutama membuat pembelajaran semakin konkret dan menarik perhatian mereka (Nisa, Oktavianti and Sumitra, 2019:347).

Penyebab ke dua yaitu guru masih memberikan penjelasan tidak jelas sehingga anak masih kaku memahami tugas yang diberikan. Terlihat belum berjalannya komunikasi yang efektif. Komunikasi yang efektif mengharuskan adanya feed back antara guru dan anak (Azzahra, Hardika and Kuswandi, 2019:137). Kemudian Azzahra,
Hardika and Kuswandi (2019:141) menyebut biasanya guru menggunakan pola komunikaksi satu arah sehingga anak lebih pasif. Maka guru diharapkan menyesuaikan dengan anak-anak usia dini sehingga informasi yang disampaikan dapat didengar dan dipahami dengan mudah. Hal ini berkaitan dengan kompetensi sosial guru (Sufiati and Afifah, 2019:52).

Berdasarkan refleksi pada siklus I, guru telah memberi perhatian yang lebih dan pemberian reward pada siswa untuk perbaikan pembelajaran sehingga terjadi peningkatan dari hasil pada pelaksanaan siklus II. Dari hasil observasi menunjukkan lebih dari $75 \%$. Dan indikator pelaksanaan pembelajaran oleh guru berada dalam kategori baik. Hal yang serupa juga terjadi pada studi Astuti, (2016:98) yaitu peningkatan kecerdasan logika matematika menggunakan kartu angka di TK Pembina Bangkinang Kota, mengalami kenaikan ketuntasan karena adanya perbaikan pembelajaran (tindakan) pada siklus sebelumnya.

Pencapaian ketuntasan lebih dari $75 \%$ juga dipengaruhi keadaan psikologi anak yang merasa nyaman dalam belajar karena penggunaan kartu angka dengan metode bermain. Mereka tidak hanya berhitung tetapi juga belajar sambil bermain dan akan mengasah psikomotorik (Aritonang \& Elshap, 2019:368). Hal ini juga dikemukakan Misrawati \& Suryana, (2021:299) bahwa media pembelajaran yang digunakan harus disesuaikan dengan kebutuhan kelas termasuk anak. pada usia dini media pembelajaran sebaiknya mengutamakan prinsip belajar sambil bermain sehingga mereka mendapatkan pengalaman untuk menumbuhkan kecintaan pada matematika. Maka sangat dituntut Pelaksanaan pembelajaran yang menarik dan bervariasi.

Pada refleksi pada tahap 1 guru menyadari pemberian reward pada siswa cukup esensial dalam pembelajaran yakni meningkatkan motivasi belajar siswa. Hal ini sebelumnya dijelaskan oleh Agustina et al., (2021:359) bahwa salah satu cara yang dilakukan guru untuk meningkatkan motivasi belajar anak usia dini dan memengaruhi aspek perkembangan serta membuat mereka lebih giat belajar. Dalam implementasinya, reward dimaksudkan sebagai penghargaan kepada 
P ISSN 2548-6284 E ISSN 2615-0360

Vol. 6 No. 1 Desember 2021

anak karena telah mengerjakan tugas secara tepat. Kondisi ini dapat membuat siswa semangat lagi dalam mengerjakan tugas dan lebih aktif dalam pembelajaran hingga mencaoau keberhasilan dalam mengerjakan tugas tertentu (Sabartiningsih et al., 2018:67). Selain itu reward berfungsi untuk menarik perhatian anak agar terdorong dalam aktivitas belajar (Sakdiah \& Winda, Mhd. Zulkifli Hasibuan, 2020:254). Sehingga pemberian reward memberikan efek menyenangkan pada anak sehingga mereka memiliki rasa percaya diri dan dihargai dalam pembelajaran. Secara tidak langsung, pemberian reward pada aktivitas belajar ikut berkongtribusi dalam peningkatan kemampuan berhitung anak usia dini.

Secara sederhana penelitian ini telah berhasil dalam meningkatkan berhitung anak. Namun demikian kemampuan guru untuk menerapkan strategi pembelajaran melalui media yang menyenangkan untuk meningkatkan kemampuan berhitug anak jauh lebih penting. Artinya tanpa strategi yang menyenangkan bagi anak kegiatan tidak akan berhasil dilakukan dan juga tanpa ada kemauan dari guru. Dengan demikian peningkatan kemampuan berhitung anak tidak akan berhasil tanpa didukung oleh kemampuan guru

\section{DAFTAR PUSTAKA}

Agustina, M., Azizah, E. N., \& Koesmadi, D. P. (2021). Pengaruh Pemberian Reward Animasi terhadap Motivasi Belajar Anak Usia Dini selama Pembelajaran Daring. Jurnal Obsesi: Jurnal Pendidikan Anak Usia Dini, 6(1), 353-361. https://doi.org/10.31004/obsesi.v6i1.1331

Arikunto, S. (2010). Prosedur Penelitian, Suatu Pendekatan Praktek. Rineka Cipta.

Aritonang, L. A., \& Elshap, D. S. (2019). Meningkatkan Kemampuan Berhitung pada Anak Usia Dini dengan Menggunakan Metode jarimatika. Jurnal Ceria, 2(6), 363369.

Astuti. (2016). Peningkatakan Kemampuan Anak Mengenal Konsep Bilangan Melalui Permainan Kartu Angka di Kelompok B TK Aisyiyah Pulau Payung Kecamatan Rumbio Jaya. 2.

Aulina, C. N. (2018). Penerapan Metode Whole

\section{SIMPULAN}

Studi implementasi penggunaan media kartu angka dapat meningkatkan kemampuan berhitung anak usia dini. Walaupun masih ada anak yang memperoleh kategori cukup akan tetapi target pembelajaran $75 \%$. Temuan penelitian ini yaitu tahap perencanaan dan komunikasi antara guru dan anak memengaruhi pencapaian tujuan pembelajaran. Selain itu pemberian reward pada siswa juga berkontribusi dalam peningkatan kemampuan berhitung anak usia dini. Secara sederhana penelitian ini telah berhasil dalam meningkatkan berhitung anak. Namun demikian kemampuan guru untuk menerapkan strategi pembelajaran melalui media yang menyenangkan untuk meningkatkan kemampuan berhitug anak jauh lebih penting. Artinya tanpa strategi yang menyenangkan bagi anak kegiatan tidak akan berhasil dilakukan dan juga tanpa ada kemauan dari guru. Dengan demikian peningkatan kemampuan berhitung anak tidak akan berhasil tanpa didukung oleh kemampuan guru, saran studi ini yakni setiap tahapan dalam implementasi media pembelajaran harus optimal, pemberian reward memberikan efek menyenangkan pada anak sehingga mereka memiliki rasa percaya diri dan dihargai dalam pembelajaran. Secara tidak langsung, pemberian reward pada aktivitas belajar ikut berkongtribusi dalam peningkatan kemampuan berhitung anak usia dini.

Brain Teaching dalam Meningkatkan Motivasi Belajar Anak Usia Dini. Jurnal Obsesi : Jurnal Pendidikan Anak Usia Dini, 2(1), https://doi.org/10.31004/obsesi.v2i1.1

Azzahra, N. A., Hardika, H., \& Kuswandi, D. (2019). Pola Komunikasi Guru dalam Pembelajaran Anak Usia Dini. Jurnal Pendidikan: Teori, Penelitian, Dan Pengembangan, 4(2), 137. https://doi.org/10.17977/jptpp.v4i2.11917

Farihah, H. (2017). Mengembangkan Kemampuan Berhitung Anak Usia Dini Melalui Kegiatan Bermain Stick Angka. Jurnal Teladan, 2(1), $1-20$.

Farrokhi, F., \& Mahmoudi-Hamidabad, A. (2012). Rethinking convenience sampling: Defining quality criteria. Theory and Practice in Language Studies, 2(4), 784-792. https://doi.org/10.4304/tpls.2.4.784-792 
P ISSN 2548-6284 E ISSN 2615-0360

Vol. 6 No. 1 Desember 2021

Hurlock. (2010). Psikologi Perkembangan Suatu Pendekatan Sepanjang Rentang Kehidupan. Erlangga.

Laily, A., Jalal, F., \& Karnadi, K. (2019). Peningkatan Kemampuan Konsep Matematika Awal Anak Usia 4-5 Tahun melalui Media Papan Semat. Jurnal Obsesi : Jurnal Pendidikan Anak Usia Dini, 3(2), 396. https://doi.org/10.31004/obsesi.v3i2.214

Malapata, E., \& Wijayanigsih, L. (2019). Meningkatkan Kemampuan Berhitung Anak Usia 4-5 Tahun melalui Media Lumbung Hitung. Jurnal Obsesi: Jurnal Pendidikan Anak Usia Dini, 3(1), 283 https://doi.org/10.31004/obsesi.v3i1.183

Misrawati, M., \& Suryana, D. (2021). Bahan Ajar Matematika Berbasis Model Pembelajaran Tematik terhadap Kemampuan Berhitung Anak Usia Dini. Jurnal Obsesi: Jurnal Pendidikan Anak Usia Dini, 6(1), 298-306. https://doi.org/10.31004/obsesi.v6i1.1249

Miswara, A., Wiyono, J., \& Ariani, N. L. (2018). Pengaruh Permainan Congklak Terhadap Peningkatan Kemampuan Berhitung Anak Usia 4-6 Tahun Di Tk Dharma Wanita Persatuan 02 Malang. Nursing News, 3(1), 697-706.

Mufarizuddin, M. (2017). Peningkatan Kecerdasaan Logika Matematika Anak melalui Bermain Kartu Angka Kelompok B di TK Pembina Bangkinang Kota. Jurnal Obsesi : Jurnal Pendidikan Anak Usia Dini, 1(1), https://doi.org/10.31004/obsesi.v1i1.32

Mulyasa. (2010). Praktek Penelitian Tindakan Kelas. Remaja Rosdakarya.

Nisa, A., Oktavianti, Y. M., \& Sumitra, A. (2019). Meningkatkan Kecerdasan Logis Matematis Pada Kelompok B Anak Usia Dini Melalui Media Pembelajaran Dadu Angka Pada Kelompok B. CERIA (Cerdas Energik Responsif Inovatif Adaptif), 2(6), 347. https://doi.org/10.22460/ceria.v2i6.p347-353

Novan, W. (2016). Konsep Dasar Pendidikan Anak Usia Dini. Gava Media.

Novianti, R. (2015). Pengembangan permainan roda putar untuk meningkatkan kemampuan berhitung angka anak usia 5-6 tahun. Jurnal Educhild, 4(1), 56-63.

Oktriyani, N. (2017). Peningkatan Kemampuan Berhitung Anak Usia Dini Melalui Permainan Lingkaran Angka Di Taman Kanak- Kanak Qatrinnada Kecamatan Koto
Implementasi Penggunaan Media .... Sri Sufliati Romba, Fadhilah Latif

Tangah Padang. PAUD Lectura: Jurnal Pendidikan Anak Usia Dini, 1(1), 83-96. http://journal.unilak.ac.id/index.php/paudlectura/article/view/510

Romlah, M., Kurniah, N., \& Wembrayarli. (2016). Peningkatan Kemampuan Berhitung Anak Melalui Kegiatan Bermain Sempoa. Jurnal Ilmiah Potensia, 1(2), 1-6. https://core.ac.uk/download/pdf/228584908. pdf

Sabartiningsih, M., Muzakki, J. A., \& Durtam. (2018). Implementasi Pemberian Reward Dan Punishment Dalam. Jurnal Pendidikan Anak, 4, 60-77. www.syekhnurjati.ac.id/jurnal/index.php/awl ady\%0AEmail:

pgrasyekhnurjati@gmail.com P-ISSN: 25414658 E-ISSN: 2528-7427\%0AVol.

Sakdiah, K., \& Winda, Mhd. Zulkifli Hasibuan, P. (2020). Pemberian Reward dalam Proses Pembelajaran terhadap Aktivitas dan. Prossiding Seminar Hasil Penelitian 2019 Universitas Muslim Nusantara, 2, 251-256. https://www.e-

prosiding.umnaw.ac.id/index.php/penelitian/ article/view/544

Setiawan, A. (2018). Meningkatkan Kemampuan Berhitung Anak Usia Dini Melalui Media Pembelajaran Matematika di RA Ma'arif 1 Kota Metro. Jurnal Program Studi PGRA, 4(Seling:Jurnal Program Studi PG), 181188.

Sufiati, V., \& Afifah, S. N. (2019). Peran perencanaan pembelajaran untuk performance mengajar guru pendidikan anak usia dini. Jurnal Pendidikan Anak, 8(1), 4853. https://doi.org/10.21831/jpa.v8i1.26609

Ulfah, M. (2018). Peningkatan Kemampuan Mengenal Angka Melalui Media Kartu Angka Pada Anak Kelompok B Tk Dwp Klampok Benjeng Gresiktahun Pelajaran 2015/2016. Jurnal Anak Usia Dini Dan Pendidikan Anak Usia Dini, 4(2), 74.

Widodo, T., \& Solehudin, Z. (2021). Influence of Social Media Marketing Activities On Customer Response With Mediation of Brand Equity In E-Wallet. E-Prooceding of Management, $\quad$ 8(2), 987. https://openlibrarypublications.telkomuniver sity.ac.id/ 